\title{
The Politics of Migrant Resistance amid the Greek Economic Crisis
}

\author{
Dimitris Skleparis \\ Hellenic Foundation for European and Foreign Policy
}

\begin{abstract}
This paper focuses on a particular instance of migrant resistance: the hunger strike of three hundred irregular migrants in 2011 in Greece. It does not conceptualize the politics of migrant resistance as an isolated incidence of mobilization of irregular migrants against the government in support for their rights in existing institutions. By drawing on a set of fifty-two face-to-face semi-structured interviews with migrant protesters and organizers of the hunger strike, this paper rather argues that the politics of migrant resistance is performed in the daily lives and day-today activities of irregular migrants. It is performed by irregular migrants and those who stand in solidarity with them through the mundane production of information, tricks for survival, mutual care, social relations, services exchange, solidarity, and sociability, which challenge security policies and controls and establish an alternative form of life. The differential inclusion of irregular migrants in various social fields, and the leeway that this inclusion potentially creates in their daily lives and social relationships, enables irregular migrants to create ties with other agents/actors in dominated positions in their social fields, who possess and control the essential capital for the creation of these alternative modes of life.
\end{abstract}

In January 2011, about three hundred irregular migrants from the Maghreb countries traveled from Chania, Crete, to Athens and Thessaloniki and started a fortyfour-day-long hunger strike. Supported by solidarity groups and NGOs, the protesters risked their lives but managed to achieve some concessions from the government, which slightly improved their legal status. This incident is not just one migrant mobilization among various others. It is the largest hunger strike in Europe's recent history, which has also involved the use of various material and human resources, triggering the state's immediate response and dividing public opinion. All these factors, together with the fact that it is the most recent mass-organized migrant mobilization and, by extension, its protagonists could be more easily approached and interviewed, influenced the focus on this event.

This paper does not conceptualize the politics of migrant resistance as an isolated incidence of mobilization of three hundred irregular migrants against the government in support for their rights in existing institutions; rather, it argues that politics of migrant resistance is performed in the daily lives and day-to-day activities of irregular migrants. It is performed by irregular migrants and those who stand in solidarity with them through the mundane production of information, tricks for survival, mutual care, social relations, services exchange, solidarity, and sociability, which challenge security policies and controls and establish an alternative form of life. This becomes possible since irregular migrants are members of, and capable of moving in, various social fields at the same time. The differential inclusion of irregular migrants 
in various social fields, and the leeway that this inclusion potentially creates in their daily lives and social relationships, enables irregular migrants to create ties with other agents/actors in dominated positions in their social fields, who possess and control the essential capital for the creation of these alternative modes of life.

Protest in Greece has captured the international media's attention in the past, amid the worst economic crisis of the country's modern history. The Greek debt crisis that started to unfold in 2010 has further exacerbated the tensions between natives and migrants and has altered the dynamic between state, citizens, and migrants. Recent developments include the rise of nationalism, populism, antiimmigration attitudes, hate crime and speech (Lazaridis and Skleparis 2016), and the curtailment of the state's capacity to provide assistance to asylum seekers and refugees (Skleparis 2015). Furthermore, in 2015 alone, more than 800,000 asylum seekers entered Europe through Greece. Meanwhile, the gradual closure of the "Western Balkan route" in the EU after the November Paris attacks has forced a large number of asylum seekers to stay in a country they don't want to, and has triggered various types of migrant protests, such as lip-sewing and hunger strikes at the Greek-FYROM border, and riots in detention centers in Greece.

This paper utilizes a set of fifty-two face-to-face semi-structured interviews with migrant protesters and organizers of the hunger strike, which were conducted in Chania, Crete, in summer 2012. The next section puts forward an outline of the theoretical and methodological framework that is employed in this paper. Next, a chronological account and further information about the context of the hunger strike, and the profile and experiences of the protesters, is provided. Finally, the paper proceeds to explore migrant agency through the three hundred hunger strikers' formation of alliances, search for capital, and power positions within social fields.

\section{The Politics of Migrant Resistance}

Two, not so distinct, approaches to the study of the politics of migrant resistance can be identified within the alternative transdisciplinary current that has been developed during the past twenty years: one that offers a critical reconceptualization of migration and citizenship (Squire 2009, 146); and another one that argues that migrants tend to act as citizens, because they are already citizens (Bojadžijev and Karakayali, cited in Mezzadra 2011).

The former approach engages with challenges to the de-politicization of exclusionary security practices, which are characterized by a rationality of solidarity and can be understood as constituting political community, governance, and belonging in terms that go beyond a territorial frame (Squire 2009, 146). Rather than perceiving refugees and migrants as passive, disempowered victims of exclusionary security politics, it focuses on the various political mobilizations through which refugees and migrants constitute themselves as political subjects (ibid.). Thus, the focus is transferred to the question of how to make the reinsertion of political agency possible, while security is conceptualized as a method of governing that affects the constitution or destitution of political agency (Huysmans and Squire 2010, 175).

Several researchers have analyzed citizenship claims as a mobile form of political agency (e.g., McNevin 2006; Moulin and Nyers 2007; Squire 2009). McNevin (2009) focuses on the growing political activism of irregular migrants in France, the United States, and Australia and interprets it as a form of contestation of citizenship, which may imply new forms of political belonging that move beyond a conventional citizen/non-citizen divide. Nyers (2003) focuses on the campaign of non-status migrants and refugees in Montreal to stop deportations. Through an analysis of their claims and mobilizations, he provides an alternative conceptualization of cosmopolitan citizenship from the perspective of the excluded; this conceptualization is located in concrete struggles and radically calls into question deeply 
held assumptions about sovereignty and border control. Moreover, Nyers (2008) analyzes acts of citizenship with regard to the growing political movement of nonstatus migrants and refugees in Canada. By examining acts of self-identification as non-status acts of claim-making and rights-taking, and acts of protest in street rallies, marches, and detention centers, he evaluates the normative and political challenges that they pose to established norms of citizenship, belonging, and political community. Finally, Nyers (2011) explores the concept of irregular citizenship by drawing on the case of a Canadian citizen in order to highlight the gradual breakdown of the dividing line between "secure citizens" and "threatening migrants." He examines both practices of "unmaking"/"irregularizing" citizenship by the state and acts of "self-irregularization" by activists who challenge liberal citizenship and exceptionalist practices of control in favor of another way of being political.

The latter approach engages with belonging through the analytic lens of capital-labor relations. It examines the connection of migrants' citizenship with a broader politics of labor subordination, and focuses on migrants' agency, where mobility is utilized by migrants as a means. In other words, migrants' subjectivity becomes the focal point and migration is understood as a political resource through which people attempt to better their lives when states and other institutions no longer provide adequate quality-of-life conditions (Rodriguez 1996; Mezzadra and Neilson 2003; Mezzadra 2004). This approach is known as the "autonomy of migration."

This approach is based on the key assumption that migration is not a by-product of socioeconomic and cultural structures, but an essential creative force in its own right, capable of escaping political sovereignty and fueling social, cultural, and economic transformations (Walters 2008). In this respect, security practices, such as border controls, are more than just an attempt to control "illegal" migration; rather, they are struggles "to resist attempts by working-class communities in peripheral countries to spatially reorganize their base of social reproduction in the global landscape" (Rodriguez 1996, 23). Accordingly, border controls follow or react to people's decision for mobility, while they do not aim to exclude them, but to include them by changing their status, making them in this way more vulnerable to labor markets. Thus, "[t] he autonomy of migration actually aims to contribute to a deeper critical understanding of the reality of exploitation" (Mezzadra 2011, 123). In this regard, "[m]igration can be understood as a strategy of becoming political" (Nyers 2008, 169), as it poses a social and political challenge to controls on freedom of movement, even though only partly intentional and selfconscious (Mezzadra 2004).

Moving in this direction, Tsianos and Karakayali (2010) focus on practices and discourses of border controls in the Aegean Sea between Greece and Turkey. They reconceptualize borders and detention centers from "below" as attempts to regulate the time, rather than the space, where transit migrants move. In this respect, transit migrants are understood not as "spatially" excluded but as "temporarily" included into a global temporal regime of labor, where they are rendered productive and exploitable by labor-market forces. This function of border controls is equally shaped by the migrants and their carriers and the policy intentions of the EU. Papadopoulos et al. (2008) make a similar point about detention centers in the Aegean Sea by arguing that they should be reconceptualized in their "temporal" dimension as "speed boxes" that "decelerate" the speed of people's movement. Finally, Andrijasevic (2010) uses the Lampedusa detention center in Italy as an example of the transformation that the European space, the formation of its citizenship, and the structure of its labor markets are going through. She maintains that detention centers and deportation practices in this region perform a "temporal" regulation of transit migration, which shapes and organizes European citizenship through the principle of differential inclusion. 
Indeed, both approaches tend to emphasize in their analyses of the politics of migrant resistance the principle of differential inclusion, or else the creation of different subjects of labor through the different modalities of entry into a country and different residence statuses, which are designated by immigration controls and legal requirements (Papadopoulos and Tsianos 2013, 181). As McNevin (2006, 141) has put it, "irregular migrants are incorporated into the political community as economic participants but [are] denied the status of insiders. They are immanent outsiders." Emphasizing the differential inclusion of mobile populations automatically points to the way in which labor, mobility, and security are governed by citizenship (Papadopoulos and Tsianos 2013, 181). Yet, we cannot think of citizenship as disconnected from sovereignty and control, since "[t]he limits of citizenship are the limits of sovereignty," and citizenship coexists with borders (ibid., 183). In this sense, the more we talk about citizenship, the more we talk about security, and the more we tend to conceptualize migrants through the prism of citizenship, the more we tend to contribute to the creation of its others (ibid., 183-84). This is because citizenship feeds from sovereignty's power to create and maintain borders that it cannot fully control, while it always remains a non-exclusionary category, since citizenship for all is a contradiction in terms (ibid.). Indeed, scholars in migration studies and political theory have highlighted the exclusionary aspect of citizenship, stating that all-encompassing inclusion within nation-states is essentially interconnected with the subordination of those left outside (Brubaker 1992; Bader 1995; Yuval-Davis 1997; Joppke 1999; Isin 2002; Wallerstein 2003).

In this regard, Papadopoulos and Tsianos $(2013,192)$ have argued that autonomy of migration has somewhat neglected the ontology of migration by focusing for too long on the discourse about citizenship rights, differential inclusion, and control. Instead, the authors have put forward an understanding of migration as "a process which relies on a multitude of other persons and things" (ibid., 190), or else as "an organising practice for supporting and facilitating freedom of movement" (ibid., 191). According to this understanding, immigrants and those who stand in solidarity with them create a "world of knowledge, which includes information, tricks for survival, of mutual care, social relations, services exchange, solidarity and sociability (ibid., 190); this "world of knowledge" can be shared, used, sustained, and expanded as immigrants and those who stand in solidarity with them contribute to it (ibid.). Within this context, irregularity is understood as a condition that is used by migrants in order to facilitate their daily lives and movements. This approach to autonomy of migration does not mean, of course, that migration operates independently of control; it rather highlights the social and subjective aspects of migration before control (ibid., 184). Indeed, a number of studies have put forward valuable accounts of the various ways in which irregular migrants create alternative forms of life in mainly local contexts with the support of humanitarian NGOs or through their participation in a multitude of institutions, such as political groups/associations, art collectives, churches, schools, ethnic community groups, and so forth (Chavez 1991; Pincetl 1994; Holston 1999; Coutin 2000, 2005; Isin 2000; Van der Leun 2003; Engbersen et al. 2006; Menjívar 2006; Kalir 2010).

Subsequently, this approach produces a different understanding of the politics of migrant resistance altogether, since contesting irregularity is not considered a political act in itself (Papadopoulos and Tsianos 2013, 186). It sees political practices of migrants not as acts of resistance, but "as attempts to create a new situation that allows those who have no part-to enter and change the conditions of social existence altogether" (ibid., 188). This approach does not conceptualize politics of migrant resistance as the mobilization of migrants against their oppressors in support for their rights in existing institutions (Bishop 2011); it rather sees the politics 
of migrant resistance as the practice of creating alternative ways of daily existence and alternative ways of living (Winner 1986). Thus, in this revisited approach, migration-or else the real struggles, practices, and tactics that escape control-is autonomous, and can remain autonomous to the extent that it creates such forms of daily existence and living (Papadopoulos and Tsianos 2013, 191). All in all, the politics of migrant resistance is an organizational ontology of alternative forms of life that has "the ability to cultivate, generate and regenerate the contents, practices and affects that facilitate the movements of mobile people" (ibid.). Papadopoulos and Tsianos call this organizational ontology "mobile commons" (ibid.).

However, Papadopoulos and Tsianos have not spelled out the methodology for studying the politics of migrant resistance through the prism of their revisited approach to autonomy of migration. This paper argues that Bourdieu's concept of field can provide valuable insights into the ways in which mobile commons is assembled and materialized.

Bourdieu's (1969) concept of field constitutes a key notion in the "Theory of Practice." The concept of field can be defined as a network, or a configuration, of objective relations between positions objectively defined, in their existence and in the determinations they impose upon their occupants, agents or institutions, by their present and potential situation ... in the structure of the distribution of power (or capital) whose possession commands access to the specific profits that are at stake in the field, as well as by their objective relation to other positions. (Wacquant 1989, 39)

In other words, the field constitutes a distinct social locus marked by interdependent and diverse positions (ibid.). It is a social arena characterized by struggles that occur over particular resources, stakes, and access to them (Jenkins 1992, 52). The field, according to Bourdieu, is a structured system of social positions that are occupied by either institutions or individuals, the status of whom dictates the condition for the agents that take them up (ibid., 53).

Bourdieu's theory "can be used to explain how people can resist power and domination in one [field] and express complicity in another" (Moncrieffe 2006, 37). Indeed, according to Bourdieu (1991, 245), those who are in similar yet distinct patterns of social relations tend to form alliances with each other. It is within this context that people at the bottom of a symbolic power system can resist domination and generate the contents, practices, and affects that nurture people's mobility and render mobile people's daily lives livable.

This assumption has led the present paper to focus on social fields where irregular migrants truly belong, and where they occupy and tend to accept subordinate positions within the power hierarchy. However, according to Bourdieu, this does not mean that there is no space for social change through resistance to domination. Resistance to domination can take place through the formation of alliances with actors and agents that lie at the bottom of the symbolic power system in other social fields. This does not mean, however, that power stops being distributed through fields in these instances of resistance, as individuals are simultaneously undergoing and exercising power (Foucault 1980, 98). Bourdieu (1991, 245-46) analyzes the ambiguous alliance between industrial workers, who are dominated in their field, and intellectuals, "the dominated among the dominant" within the field of power. Through the formation of a more or less durable alliance based on a "conscious misunderstanding," the latter supply to the former, "by a sort of embezzlement of accumulated cultural capital, the means of constituting objectively their vision of the world" (ibid., 245). Thus, it is expected that the three hundred irregular migrants that went on a hunger strike in Greece sought and eventually formed alliances with agents that were dominated in their social fields in order to help in the defense and extension of mobile commons; or else, in order to assist in the facilitation of irregular migrants' daily lives and 
movements. In this respect, it is expected that one group will help the other because of the similarity/homology of their condition (ibid.).

\section{A Chronology of the Hunger Strike}

Four months prior to the commencement of the hunger strike, "Migrants' Forum in Crete," a local NGO based in Chania, conceptualized and scheduled the protest for November 2010 (Papagiannis 2011). Yet, various obstacles forced the NGO to postpone the protest until January 2011, despite the fact that the buildings that would host the hunger strikers had already been chosen: the Athens Law School and the Thessaloniki Labor Centre. On January 21, 2011, members of the "Initiative for Solidarity" occupied an unused, newly refurbished building of the Athens Law School-a deeply symbolic building (Walsh and Tsilimpounidi 2012). ${ }^{1}$ In the meantime, other members of the "Initiative for Solidarity" went to Chania in order to accompany the protesters to the occupied buildings in Athens and Thessaloniki. Two days later, the protesters had reached the venues and, on January 25, the hunger strike began in Athens and Thessaloniki simultaneously. In total, two hundred eighty-seven irregular migrants participated in the hunger strike, following thirteen last-minute withdrawals: two hundred thirty-seven protesters in the Athens Law School and fifty in the Labor Centre in Thessaloniki.

Inevitably, the hunger strike-an uncommon form of protest that falls outside the normal "protest repertoires" (Tilly 1995, 26) and "collective action frames" (Tarrow 1992) - attracted significant national and international media attention and polarized Greek public opinion. Some of those who supported the protest joined the "Initiative for Solidarity," which organized demonstrations and music concerts, among other events, in support of the protesters. The hunger strikers, on the other hand, formed their own collective body, the "Assembly of Migrant Hunger Strikers." Each body held daily separate meetings, but there was also communication between them across the two cities via webcams.

On January 28, the protesters were escorted by the police and members of the "Initiative for Solidarity" to a nearby privately owned building called "Ypatia," after they were forced to evacuate the Athens Law School building amid great pressure from state authorities. In the meantime, the hunger strike in Thessaloniki continued uninterrupted. The transfer of the protesters to "Ypatia" not only removed them from the public sphere (Mantanika and Kouki 2011), but the hunger strikers also complained that many of them were forced to sleep outdoors in tents, due to the building's space limitations. Nevertheless, the protesters, through their spokespersons and those who stood in solidarity with them, attempted to communicate and publicize their grievances through press conferences, interviews, the distribution of brochures, and the organization of events such as concerts and marches (Karyotis and Skleparis 2014).

Throughout the hunger strike, the medical team of the solidarity movement was monitoring the deteriorating health of the protesters. On the seventeenth day of the hunger strike, seven participants were withdrawn from the protest on medical grounds, while a number of others were hospitalized during the fortyfour days of the hunger strike's duration. Despite the possibility of loss of human lives, which would be a blow to the government's legitimacy and image (Dingley and Mollica 2007), state officials refrained from meeting with the hunger strikers' representatives until the later phase of the protest. On March 9, 2011, a deal was reached with the government that put an end to the hunger strike in return for some changes to the protesters' legal status. Instead of full regularization, the protesters were offered a biannually renewable status of "indefinite tolerance,"

\footnotetext{
${ }^{1}$ The Athens Law School is a symbol of the struggle against the military dictatorship, as the student demonstrations that started from that building in 1973 resulted in the fall of the regime a few months later.
} 
permission to visit their countries of origin, and a promise to be granted work permits. Furthermore, the government conceded to the regularization of all migrants in Greece who could prove their continuous residence in the country for at least a decade, knowing full well that the vast majority of migrants in Greece would be unable to provide the necessary supporting documents for the implementation of this measure, as past experience had proven (see Fakiolas 2003). Last but not least, the deal with the government included the reduction of the necessary pension credits for the annual renewal of residence permits of all migrants from two hundred to one hundred and twenty, and the reduction of the essential credits for the issue of health insurance booklets from one hundred to sixty (Karyotis and Skleparis 2014).

\section{The Three Hundred Irregular Migrant Hunger Strikers}

All of the interviewees were Maghreb nationals: forty-eight Moroccans, two Algerians, and two Tunisians. Moreover, nine out of ten were in their mid-to-late twenties and single. With respect to their employment status, $40 \%$ had a full-time job, $37 \%$ were working part-time, and $19 \%$ were unemployed at the time of the interview. The majority of the interviewees were primarily employed in the construction sector, as well as in the tourist industry and agriculture. Similar to the Greek citizens, the economic crisis had gravely affected the living conditions of the interviewees, as nine out of ten admitted that their life was worse compared to before the crisis. The scarcity of employment opportunities amid the economic crisis was identified as the main problem by almost all interviewees. Increased racism and anti-immigration discourse in the realm of politics was also a significant cause of concern, although only a large minority, $46 \%$, had a first-person experience of either verbal or physical abuse.

Furthermore, seven out of ten interviewees had been living in Greece for more than five years. Only one out of ten respondents initially came to Greece through a legal channel (i.e., a student or tourist visa). The rest entered Greece irregularly via the Greek-Turkish sea border $(70 \%)$ or the Greek-Turkish land border $(21 \%)$. The most important reasons for entering Greece were to use the country as a transit to another EU member-state $(69 \%)$, or to pursue better living conditions $(64 \%)$ or employment $(62 \%)$. These findings challenge two well-known migration pull factors - the knowledge of welfare provisions and the presence of existing large migrant communities-which do not apply in this case (Karyotis and Skleparis 2014). All in all, 60\% stated that they would like to move elsewhere in the EU or go back to their country of origin.

Figure 2 demonstrates the attitudes of the hunger strikers regarding the role that main actors played, directly or indirectly, in the protest. Unsurprisingly, the role of solidarity groups $(92 \%)$ and the hunger strike organizers $(67 \%)$ was evaluated positively by the majority of the interviewees. By contrast, the role of the government $(8 \%)$ and the police $(17 \%)$ in the hunger strike was evaluated positively only by a small minority. All in all, the limited concessions and broken promises of the government left a sour taste in the mouth of the hunger strikers (Karyotis and Skleparis 2016). Indeed, the mean average of the interviewees' responses with respect to the level of fulfilment of the goals of the hunger strike was just 3.1 on a $0-10$ scale, where 0 means "not at all" and 10 means "absolutely," which reflects the disappointment of the participants about its outcomes (Karyotis and Skleparis 2014).

\section{The Formation of Alliances and the Search for Capital}

Social networks and NGOs were instrumental in the organization of the three hundred irregular migrants' hunger strike. Support came from migrant groups 


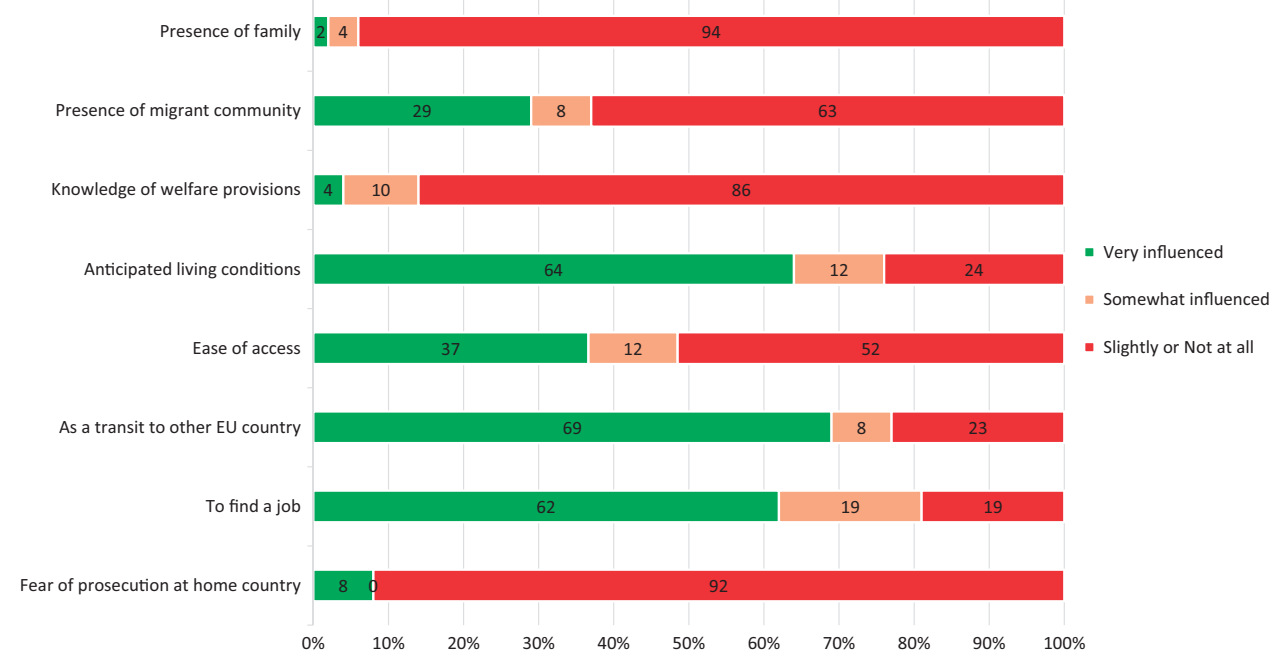

Figure 1. Influence of push and pull migration factors

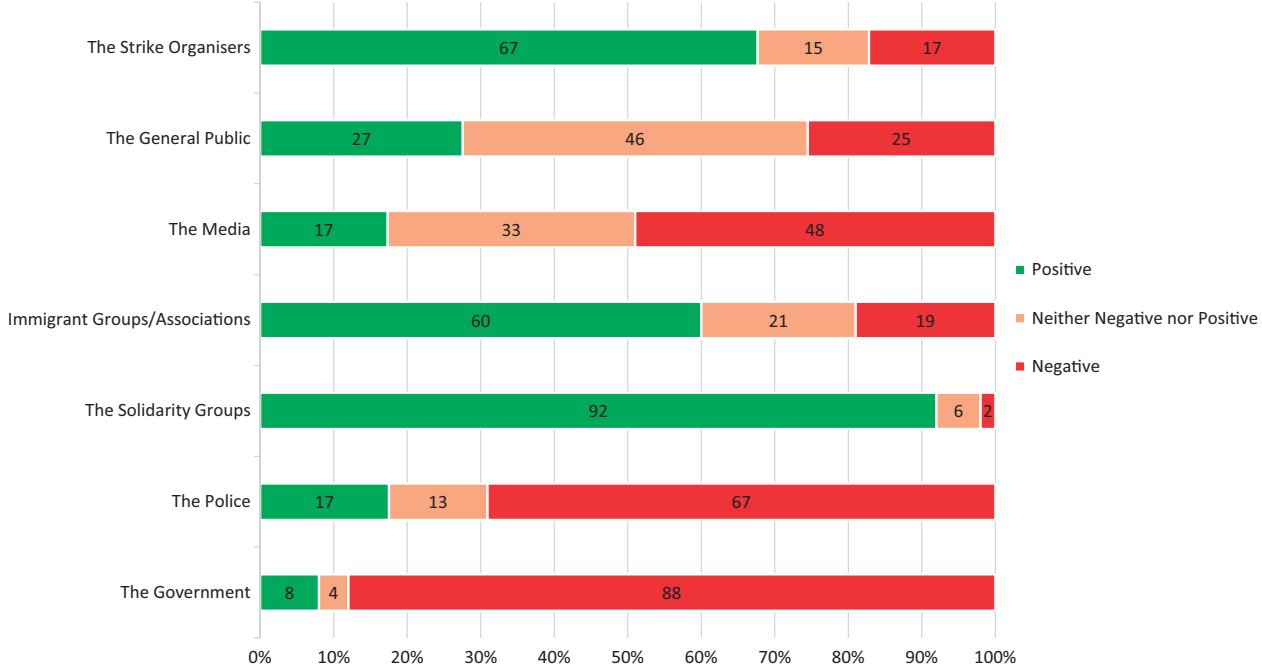

Figure 2. Evaluation of key actors involved in the protest

and networks, NGOs, antiracist and university student bodies, labor associations, neighborhood initiatives, anarchist collectives, and political parties, particularly those to the left of the ideological spectrum. Members of these actors joined forces to create the "Initiative for Solidarity" with the hunger strikers. Yet, these alliances with dominated actors in their social fields were not opportunistic; rather, they were based on pre-existing organizational networks and social relationships, or in other words on pre-existing systems of production of mobile commons, which facilitated the mobilization, or else the maintenance/defense and expansion of mobile commons.

Members of the Migrants' Forum in Crete conceptualized and started the preparations for the hunger strike months before the actual protest took place. Indeed, the NGO played a key role in the protest. This collective, formed in February 2007 in Chania, is composed of both native and migrant members, and claims regularization of all immigrants in Greece. It is a very politically active 
group, and its repertoire of actions includes dissemination of information and raising awareness regarding the problems of migrants and refugees, intervention at the level of political institutions, and the organization of various forms of collective action such as leafleting, marches, demonstrations, football games, concerts, and more radical forms of protest. Indeed, the Migrants' Forum in Crete organized both the $2008^{2}$ and 2011 hunger strikes. Moreover, it is a network hub with strong ties with various other organizations, such as the "Maghreb Arabi Association." The latter is also based in Chania and was founded in 2006. Its members are exclusively nationals from the Maghreb countries. The ties between these two organizations are so strong that they share the same headquarters and all Maghreb Arabi Association members are also members of the Migrants' Forum in Crete.

This explains why both hunger strikes were based on ethnic mobilization. With regard to the 2011 hunger strike mobilization, a small core of volunteers initiated a campaign to recruit participants on a door-to-door basis. Concurrently, other volunteers went to Athens, Thessaloniki, and Volos to mobilize further support, explore options, and assess the feasibility of the planned action. Indeed, data confirm that nine out of ten interviewees first heard about the hunger strike through face-to-face contact.

However, the role of social networks is not confined to the organization of the hunger strike and the recruitment of participants. A few days prior to the commencement of the protest, left-wing university student parties proposed, during an assembly of Athens Law School students, the occupation of one of the school's buildings in order to host the hunger strikers. Their proposal was accepted by the student body, despite the fact that other student parties strongly opposed the decision. Eventually, on January 21, 2011, members of the solidarity movement occupied a building of the Athens Law School and paved the way for the imminent commencement of the strike. Moreover, as previously mentioned, other members of the solidarity initiative traveled to Chania to accompany the migrants to the venues, on rented buses, where required. In addition, when the government made clear that the hunger strikers had to evacuate the Athens Law School building, members from the solidarity initiative participated in the search for a new place that could host the protesters.

Furthermore, on January 28, the third day of the strike, when hunger strikers were forced by the police to evacuate the Law School building, it was the solidarity initiative and numerous other supporters that escorted and marched with the protesters to the new building that would host the hunger strikers. And when this building was found unsuitable to host all of the protesters due to space limitations, it was a nearby squat that eagerly accommodated some of the hunger strikers till arrangements were made. Moreover, it was the solidarity initiative's medical team that monitored the health of the protesters throughout the strike and it was members of the initiative and other supporters that escorted some of the strikers to the hospitals when needed. Finally, it was the spokespersons and supporters of the hunger strike that, during the protest, publicized the participants' grievances through press conferences, interviews, distribution of leaflets, and the organization of events including music concerts and marches. All these constitute evidence that the hunger strike could not have taken place without the crucial support of its allies.

These findings are in accordance with Bourdieu's thoughts on resistance, which suggest that in such instances, individuals/groups at the bottom of the power hierarchy within a field tend to form alliances with other individuals/groups in a

\footnotetext{
${ }^{2}$ On November 11, 2008, fifteen irregular migrants from the Maghreb countries started a twenty-six-day hunger strike outside Chania Town Hall, which forced the government to concede to their demands and grant them residence and work permits.
} 
similar situation who possess and have the ability to control cultural/symbolic capital. Yet, these findings also suggest that the alliances that were formed were neither random nor opportunistic, as they were based on the pre-existing organizational networks and social relationships that can be found within a field. In fact, a large majority of the respondents $(62 \%)$ were members of either the Migrants' Forum in Crete or the Maghreb Arabi Association-in other words, the very actors that assisted in the organization of the hunger strike in the beginning. What is more, individuals/groups with access to symbolic, material, and human capital are particularly sought as potential allies in instances of maintenance/defense and the expansion of mobile commons.

Thus, material, symbolic, and human capital also played a crucial role in the zsuccessful 2011 hunger strike mobilization. Regarding the former, each member of the Migrants' Forum in Crete is obliged to contribute on a monthly basis a small amount of money depending on his/her income. If the member has no income, there can be an exemption from this obligation. Thus, every month volunteers collect the membership fee, which helps cover the running expenses of the collective. This policy of monetary contributions proved to be particularly useful prior to and during the hunger strike. For instance, the expenses for the ferry tickets of the hunger strikers from Chania to Athens were partly covered by these fees. The rest of the ticket expenses as well as other expenses incurred by the hunger strike were covered by emergency contributions by the solidarity initiative.

In terms of human and symbolic capital, one must take into account the experience acquired from the 2008 hunger strike. The actors that organized this protest were the same as those who organized the 2011 hunger strike: the Migrants' Forum in Crete and the Maghreb Arabi Association. Apart from the experience of organizing a successful hunger strike, the human and symbolic capital available to the three hundred hunger strikers also included a network of supporters, which was formed and galvanized in the 2008 mobilization. Moreover, one should not ignore the $15 \%$ of the respondents that participated, in one form or another, in the 2008 hunger strike. These migrants were an invaluable asset to the 2011 hunger strike as they transferred their "status," firsthand experience, and know-how to the new mobilization. Finally, we should also consider the important role of militants and leadership in the successful mobilization. Indeed, according to a public statement of the Migrants' Forum in Crete (2011), the hunger strikers were "pioneers of the migration movement," who constituted "by far its most progressive part."

This section demonstrated the crucial role that alliances played in the organization of the hunger strike, the recruitment of participants, and the maintenance of the protest; or in other words, in the maintenance/defense and expansion of mobile commons. It is safe to argue that the three hundred irregular migrants' hunger strike could not have taken place without the availability of pre-existing networks of allies that were willing to support it; or else, the hunger strike could not have taken place without pre-existing systems of production of mobile commons willing to defend relations of justice amid current capitalist power and sovereign control. Moreover, this section underlined the key role of material, human, and symbolic capital in the generation of mobile commons. Without the membership money of the Migrants' Forum in Crete and the emergency contributions of the supporters; without the experience and know-how from a previous hunger strike; without the people that could transfer these assets from one protest to another; and without the availability of skilled and active militants that could guide the mobilization, it is doubtful whether the 2011 hunger strike could have ever taken place. These findings are in line with Papadopoulos's and Tsianos's work on the idea of mobile commons. Yet, these findings also suggest that alliances-which are of fundamental importance in the creation, maintenance, and expansion of mobile 
commons-between disempowered actors within different fields are not formed on an opportunistic basis, but they follow a pattern of pre-existing organizational networks and social relationships, while actors who possess symbolic, material, and/or human capital play key roles in the formation of alliances. Indeed, the hunger strike, as a process of maintenance and expansion of mobile commons, was itself the outcome of a process of generation of mobile commons.

\section{Irregular Migrants, Social Fields, and Daily Resistance}

The three hundred irregular migrants in Greece formed alliances with a number of actors and agents that were dominated in their social fields: migrant groups and networks, NGOs, antiracist and university student bodies, labor associations, neighborhood initiatives, anarchist collectives, political parties, and so forth. Particularly those to the left of the ideological spectrum joined forces to create the "Initiative for Solidarity" with the hunger strikers. The "Initiative for Solidarity" provided the hunger strikers with the essential cultural capital in order to claim their vision of the world. These alliances were not formed on an opportunistic basis. They followed a pattern of pre-existing organizational networks and social relationships, while actors who possessed symbolic, material, and/or human capital played a crucial role in the formation of these alliances. It is the social field as a whole within which irregular migrants live that has the potential to generate mobile commons, and allows for the formation of such alliances, which can maintain and extend mobile commons. This paper calls for a careful examination of the very position that dominated agents/actors occupy within a field, as it can play a key role in the process of creation of mobile commons on a daily basis.

Even within the context of securitization of migration in Greece (Karyotis and Patrikios 2010; Karyotis 2012; Karyotis and Skleparis 2013; Lazaridis and Skleparis 2016; Skleparis 2016), alternative ways of daily existence and of living are still possible (Karyotis and Skleparis 2016). This happens because irregular migrants move in various social fields simultaneously. All in all, the fact that irregular migrants lie at the bottom of the power hierarchy does not rule out the possibility that they can enjoy considerable leeway in their daily lives and social relationships within various social fields, such as the economy, healthcare, housing, and public transport. It is within these fields that irregular migrants in Greece resist domination in their daily lives, despite their subordinate position, by using their irregularity as a means to facilitate their daily existence and movements. Irregularity does not essentially entail more subordination, but rather a form of resistance to state control (Garcés-Mascareñas 2015).

Greek legislation has explicitly securitized and criminalized irregular migrants' access to labor and housing markets, healthcare services, and public transportation. With regard to their level of access to the labor market, about nine out of ten protesters responded that they were dissatisfied. This answer has to do with Greek legislation being particularly strict regarding the inclusion of irregular migrants in the labor market, as it has defined penalties for employers who hire irregular migrants (Law 3386/2005). Indeed, Law 3386/2005 has criminalized any form of solidarity from the private sector, such as access to employment.

Prior to the economic crisis, migrants without work permits were not entirely banned from the labor market. Rather, the securitization of irregular migrants' access to the labor market rendered them vulnerable to labor exploitation and their relations with their employers precarious (De Giorgi 2010). Greek legislation was, and still is, very restrictive, excluding migrants without work permits from the labor market and defining severe penalties for those who employ them. However, in reality, employers seemed to prefer (and still do) irregular migrants over native ones in certain jobs, due to the fact that they constitute a very cheap 
and hardworking labor force (Calavita 2003). In other words, irregular migrants had opportunities for inclusion in the labor market, albeit opportunities that rendered them vulnerable to severe labor exploitation due to the unregulated character of their labor relations. Thus, despite all obstacles, irregular migrants were enjoying considerable leeway in their daily lives and social relations within the economic field prior to the economic crisis. Irregular migrants were able to find a job through their social relations, even if it was insecure, underpaid, and/or without health insurance. Indeed, "[t] he mobile commons is not outside of existing relations of production, reproduction and even exploitation" (Papadopoulos and Tsianos 2013, 191).

Yet, the economic crisis meant fewer jobs and lower salaries for both migrants and natives, and one of the sectors that was immediately affected by the crisis was that of construction; that is, the sector where the majority of the respondents were, and still are, employed. Thus, the economic crisis played a significant role in the exacerbation of the already problematic differential inclusion of irregular migrants in the labor market. The impact of the economic crisis has been uniformly detrimental to the respondents' living conditions, with nine out of ten interviewees noting that their life is worse compared to before the crisis. Along these lines, the scarcity of employment opportunities was mentioned as the main issue of concern by almost all respondents, which justifies the aforementioned dissatisfaction.

Regarding the level of access of irregular migrants to the housing market, eight out of ten interviewees expressed their satisfaction. This is surprising if one considers the restrictive nature of the relevant legislation, which bans irregular migrants from renting a house altogether. Yet, landlords in Greece very often defy the severe penalties that the law foresees for those who provide housing to irregular migrants. The ongoing economic crisis and the plethora of empty houses that it created only strengthened this tendency. Thus, the regulation of illegal housing in Greece is only in theory securitized, as in reality irregular migrants enjoy significant leeway in the housing field-there is always somebody that knows someone who can provide an affordable flat.

Moreover, half of the interviewees answered that they were dissatisfied with their level of access to healthcare services. In general, this is a low percentage of dissatisfaction considering that Greek legislation bans the provision of free healthcare services to irregular migrants, except in emergency cases (Law 3386/2005). In this respect, one would expect that the respondents would have been unable to get any medical care and by extension they would have voiced much higher levels of dissatisfaction. However, one has to take into account the local context where the respondents resided. In other words, the micro-society of Chania helped irregular migrants through interpersonal relations/ties and acquaintances get informal access to healthcare services. Additionally, those interviewees who expressed satisfaction with their level of access to healthcare services could have been the most embedded in local NGOs and, thus, could have been able to take advantage of potential links with healthcare units. Finally, one cannot dismiss the possibility that doctors simply defied the law and provided their services to irregular migrants out of pure empathy and humanitarianism. Thus, despite the securitization of irregular migrants' access to healthcare services, they still have some opportunities for inclusion in practice, even if it is informal and at the local level.

Finally, $77 \%$ of the interviewees expressed satisfaction with their level of access to public transport. Again, this is surprising if one takes into account that Greek legislation bans irregular migrants from using means of public transportation, while it foresees severe penalties, similar to those for trafficking, for the offenders (Law 3386/2005). Nevertheless, despite the restrictive legislation, the controls in means of public transportation, such as buses and taxis, are almost non-existent. 
Furthermore, ferry, coach, and train controls on internal routes are deficient. Indeed, this argument is supported by the fact that the two hundred eighty-seven irregular migrants managed to travel by ferry from Chania to Athens, and then fifty of them by coach from Athens to Thessaloniki, completely uninterrupted. Thus, although irregular migrants' access to the field of public transport appears to be securitized, there is still significant leeway available in their internal movement.

Although the interviews with the protesters were conducted 1.5 years after the end of the hunger strike, when the protesters had some form of legal residence, these findings are indicative of the protesters' feelings of frustration prior to their mobilization too. Indeed, when the interviewees were asked about their life changes after their participation in the hunger strike, they addressed various positive (e.g., ability to visit home country, residence permit) and/or negative (e.g., mental and health problems, loss of job) changes. Additionally, they identified changes in the attitudes of Greeks toward them for better (e.g., less harassment in the street by the police) or for worse (e.g., stigmatization due to participation in the hunger strike). However, none of the interviewees mentioned changes with regard to their access to the labor market, housing, healthcare services, and public transportation, which suggests that their respective levels of satisfaction/dissatisfaction as regular migrants are indicative of their prior status as irregular migrants.

All in all, these findings suggest that despite the protesters' position at the bottom of the power hierarchy, they were still able to enjoy significant leeway in their daily lives and social relations prior to the hunger strike in various social fields, such as the economy, housing, healthcare, and public transport. This is explained by the fact that irregular migrants are members of, and are capable of moving in, various social fields. Indeed, the fact that individuals/groups are dominated in a field does not rule out the possibility that these very individuals/groups can enter into power struggles and resist domination in their daily lives in various other social fields. In the case of the irregular migrant hunger strikers, the protesters drew upon their relations of care and support—such as mutual cooperation, friendships, favors that you never return, affective support, and so forth-in the fields of economy, healthcare, housing, and public transport in order to change their daily lives and make them more livable amid current capitalist power and sovereign control. These pre-existing organizational networks and social relationships or, in other words, these mobile commons rendered the maintenance/defense and further extension of mobile commons through the hunger strike feasible.

All in all, mobile commons is assembled and materialized in various fields of daily life: i) in a multiplicity of informal economies, where irregular migrants' access to not easily accessible public or private services can be facilitated through the provision of information regarding, for instance, how to find and how to pay a doctor or a lawyer; how to find short-term or more permanent employment; how to send and receive money; how to get the necessary papers for your move; and how to pay for your rent and how to find the right intermediaries, among others (Papadopoulos and Tsianos 2013, 191); ii) in diverse forms of transnational communities of justice, such as alliances and coalitions between different groups, local governments, social movements, political organizations, NGOs, and so forth, where irregular migrants can acquire access to power and self-organization (ibid.); and iii) in the field of care, which includes relations of care and support, such as mutual cooperation, friendships, favors that you never return, affective support, trust, transnational relations of care, and so forth (ibid., 192).

Thus, the politics of migrant resistance, according to this revisited approach to autonomy of migration, aims to facilitate migration through the multiplication, spreading and extending any of the aforementioned properties of mobile commons, through the installation of relations of justice by a multiplicity of actors 
amid current capitalist power and sovereign control (ibid.). It is a form of thick justice, which can be achieved through changing daily life in a way that enables people to move when they want or need to, and to live a livable life in the place where they choose to reside (ibid.).

\section{Conclusion}

This paper argued that the politics of migrant resistance is performed in the daily lives and day-to-day activities of irregular migrants. It is performed through the mundane generation of mobile commons, a political act of resistance in itself, which can potentially lead to instances of maintenance/defense and extension of mobile commons, such as the hunger strike of the three hundred irregular migrants in Greece. Both in the day-to-day generation of mobile commons and the instances of maintenance/defense and extension of mobile commons, the formation of alliances with actors/agents who possess cultural, symbolic, material, and/or human capital is equally important. In the case of the three hundred irregular migrant hunger strikers, migrant groups and networks, NGOs, antiracist and university student bodies, labor associations, neighborhood initiatives, anarchist collectives, random people who stand in solidarity with migrants, and political parties, particularly those to the left of the ideological spectrum, assisted in the creation of alternative ways of daily existence and alternative ways of living. In other words, irregular migrants and those who stand in solidarity with them created a "world of knowledge," which included information, tricks for survival, mutual care, social relations, services exchange, solidarity, and sociability, which resisted security policies and controls, establishing an alternative form of life. Hence, when the existence of this mobile commons was threatened by the economic crisis and an imminent migration law amendment (see Karyotis and Skleparis 2014, 2016), irregular migrants turned for support to pre-existing organizational networks and social relationships or, in other words, to pre-existing systems of production of mobile commons, in order to defend, maintain, and extend it through the hunger strike mobilization. This was possible due to the fact that irregular migrants are members of, and capable of moving in, various social fields at the same time. The differential inclusion of irregular migrants in Greece in the fields of economy, housing, healthcare, and public transport, and the considerable leeway that they enjoyed in their daily lives and social relationships therein, enabled irregular migrants to create ties with other agents/actors, in homological positions in their social fields, who possessed and controlled cultural, symbolic, material, and/or human capital.

This paper drew upon a revisited approach to autonomy of migration, which introduces the idea of mobile commons-that is, the facilitation of migration through the installation of relations of justice by a multiplicity of actors amid current capitalist power and sovereign control. This paper attempted to make a methodological contribution to autonomy of migration, which draws upon Bourdieu's thoughts on resistance. Bourdieu's theory "can be used to explain how people can resist power and domination in one [field] and express complicity in another" (Moncrieffe 2006, 37). According to this line of thought, actors/ agents who occupy and tend to accept subordinate positions within the power hierarchy of a field tend to form alliances with actors/agents in homological positions in other fields. This paper provided support for Bourdieu's argument that dominated actors/agents resist domination through the formation of alliances with actors/agents who occupy similar positions. Yet, it added that these alliances are not formed on an opportunistic basis; rather, they follow pre-existing organizational networks and social relationships and are formed on a day-to-day basis with actors/agents who possess cultural, symbolic, material, and/or human 
capital. In this respect, the production, maintenance/defense, and expansion of mobile commons depends on the existence of durable alliances with dominated agents/actors in various social fields who possess and control cultural, symbolic, material, and/or human capital.

\section{References}

Andrijasevic, Rutvica. 2010. Migration, Agency and Citizenship in Sex Trafficking. New York: Palgrave Macmillan.

Bader, Veit. 1995. "Citizenship and Exclusion: Radical Democracy, Community, and Justice. Or, What Is Wrong with Communitarianism?" Political Theory 23 (2): 211-46.

Bishop, Hywel. 2011. The Worlds That Migrants Are Making: The Politics of Care and Transnational Mobility. Unpublished PhD dissertation, Cardiff University.

Bourdieu, Pierre. 1969. "Intellectual Field and Creative Project." Social Science Information 8: 89-119.

- 1991. Language and Symbolic Power. Cambridge: Polity.

Brubaker, Rogers. 1992. Citizenship and Nationhood in France and Germany. Cambridge, MA: Harvard University Press.

Calavita, Kitty. 2003. "A 'Reserve Army of Delinquents': The Criminalization and Economic Punishment of Immigrants in Spain.” Punishment Eै Society 5 (4): 399-413.

Chavez, Leo R. 1991. "Outside the Imagined Community: Undocumented Settlers and Experiences of Incorporation.” American Ethnologist 18 (2): 257-78.

Coutin, Susan Bibler. 2000. Legalizing Moves: Salvadoran Immigrants' Struggle for U.S. Residency. Ann Arbor: University of Michigan Press.

—. 2005. "Contesting Criminality: Illegal Immigration and the Spatialization of Illegality." Theoretical Criminology 1 (9): 5-33.

De Giorgi, Alessandro. 2010. "Immigration Control, Post-Fordism, and Less Eligibility: A Materialist Critique of the Criminalization of Immigration Across Europe." Punishment EF Society 12 (2): $147-67$.

Dingley, James, and Marcello Mollica. 2007. "The Human Body as a Terrorist Weapon: Hunger Strikes and Suicide Bombers.” Studies in Conflict and Terrorism 30 (6): 459-92.

Engbersen, Godfried, Marion Van San, and Arjen Leerkes. 2006. "A Room with a View: Irregular Migrants in the Legal Capital of the World." Ethnography 7 (2): 209-42.

Fakiolas, Rossetos. 2003. "Regularising Undocumented Immigrants in Greece: Procedures and Effects." Journal of Ethnic and Migration Studies 29 (3): 535-61.

Foucault, Michel. 1980. Power/Knowledge: Selected Interviews and Other Writings 1972-1977. London: Harvester Press.

Garcés-Mascareñas, Blanca. 2015. "Revisiting Bordering Practices: Irregular Migration, Borders, and Citizenship in Malaysia." International Political Sociology 9 (2): 128-42.

Holston, James. 1999. Cities and Citizenship. Durham, NC: Duke University Press.

Huysmans, Jef, and Vicki SQuire. 2010. "Migration and Security." In The Routledge Handbook of Security Studies, edited by Myriam Dunn Cavelty, Victor Mauer, and Thierry Balzacq. London: Routledge. 169-79.

Isin, Engin F. 2000. Democracy, Citizenship and the Global City. New York: Routledge.

- 2002. Being Political: Genealogies of Citizenship. Minneapolis: University of Minnesota Press.

Jenkins, Richard. 1992. Pierre Bourdieu. London: Routledge.

Joppke, Christian. 1999. "How Immigration Is Changing Citizenship: A Comparative View." Ethnic and Racial Studies 22 (4): 629-52.

KALIR, BARAK. 2010. Latino Migrants in the Jewish State: Undocumented Lives in Israel. Bloomington: Indiana University Press.

Karyotis, Georgios. 2012. "Securitization of Migration in Greece: Process, Motives and Implications." International Political Sociology 6 (4): 390-408.

Karyotis, Georgios, and Stratos Patrikios. 2010. "Religion, Securitization and Anti-Immigration Attitudes: The Case of Greece." Journal of Peace Research 47 (1): 43-57.

Karyotis, Georgios, and Dimitris Skleparis. 2013. "Qui Bono? The Winners and Losers of Securitising Migration." Griffith Law Review 22 (3): 683-706.

- 2014. "Migrant Mobilisation During the Economic Crisis: Identity Formation and Dilemmas." In Remapping "Crisis": A Guide to Athens, edited by Myrto Tsilimpounidi and Aylwyn Walsh. Ropley, Hampshire: Zero Books. 124-43. 
2016. "Resistance to the Criminalization of Migration: Migrant Protest in Greece." In The Immigrant Other, edited by Greg Lamphear, Rich Furman, and Douglas Epps. New York: Columbia University Press. 266-82.

Lazaridis, Gabriella, and Dimitris Skleparis. 2016. "Securitization of Migration and the Far Right: The Case of Greek Security Professionals.” International Migration 54 (2): 176-92.

Mantanika, Regina, and Hara Kouki. 2011. "The Spatiality of a Social Struggle in Greece at the Time of the IMF." City: Analysis of Urban Trends, Culture, Theory, Policy, Action 15 (3-4): 482-90.

McNevin, Anne. 2006. "Political Belonging in a Neoliberal Era: The Struggle of the Sans-Papiers." Citizenship Studies 10 (2): 135-51.

—. 2009. "Contesting Citizenship: Irregular Migrants and Strategic Possibilities for Political Belonging." New Political Science 31 (2): 163-81.

Menjívar, Cecilia. 2006. "Liminal Legality: Salvadoran and Guatemalan Immigrants' Lives in the United States." American Journal of Sociology 111 (4): 999-1037.

Mezzadra, SAndro. 2004. "The Right to Escape." Ephemera: Theory Eo Politics in Organization 4 (3): 267-75.

— 2011. "The Gaze of Autonomy: Capitalism, Migration and Social Struggles." In The Contested Politics of Mobility: Borderzones and Irregularity, edited by Vicki Squire. London: Routledge. 121-43.

Mezzadra, Sandro, and Brett Neilson. 2003. "Né qui, né altrove: Migration, Detention, Desertion. A Dialogue." Borderlands e-journal 2 (1).

Migrants' Forum in Crete. 2011. Press Release: Statement of the Migrants' Forum in Crete, January 26. Accessed November 13, 2015. http://hungerstrike300.espivblogs.net.

Moncrieffe, Joy. 2006. "The Power of Stigma: Encounters with 'Street Children' and 'Restavecs' in Haiti." IDS Bulletin 37 (6): 31-46.

Moulin, Carolina, and Peter Nyers. 2007. "'We Live in a Country of UNHCR'-Refugee Protests and Global Political Society.” International Political Sociology 1 (4): 356-72.

Nyers, Peter. 2003. "Abject Cosmopolitanism: The Politics of Protection in the Anti-Deportation Movement." Third World Quarterly 24 (6): 1069-93.

— . 2008. "No One Is Illegal Between City and Nation." In Acts of Citizenship, edited by Engin F. Isin and Greg Marc Nielsen. London: Zed Books. 160-81.

—. 2011. "Forms of Irregular Citizenship." In The Contested Politics of Mobility: Borderzones and Irregularity, edited by Vicki Squire. London: Routledge. 184-98.

Papadopoulos, Dimitris, and Vassilis S. Tsianos. 2013. "After Citizenship: Autonomy of Migration, Organisational Ontology and Mobile Commons.” Citizenship Studies 17 (2): 178-96.

Papadopoulos, Dimitris, Niamh Stephenson, and Vassilis S. Tsianos. 2008. Escape Routes: Control and Subversion in the Twenty-First Century. London: Pluto Press.

Papagiannis, Kostas. 2011. "The 237 Migrant Hunger Strikers: 'We Are Determined to Go to the End.” Avgi, January 30. Accessed November 13, 2015. http://www.avgi.gr/ArticleActionshow .action?articleID $=596138$.

Pincetl, Stephanie. 1994. "Challenges to Citizenship: Latino Immigrants and Political Organization in the Los Angeles Area." Environment and Planning A 26 (6): 895-914.

Rodriguez, NÉstor. 1996. "The Battle for the Border: Notes on Autonomous Migration, Transnational Communities, and the State." Social Justice 23 (3): 21-37.

Skleparis, Dimitris. 2015. "Towards a Hybrid 'Shadow State'? The Case of Migrant-/Refugee-Serving NGOs." In Austerity and the Third Sector in Greece: Civil Society at the European Frontline, edited by Jennifer Clarke, Asteris Huliaras, and Dimitri A. Sotiropoulos. Farnham: Ashgate/Gower. 147-65.

- 2016. "(In)securitization and Illiberal Practices on the Fringe of the EU." European Security 25 (1): 92-111.

SQUiRE, VICKI. 2009. The Exclusionary Politics of Asylum. Basingstoke: Palgrave Macmillan.

TARrow, Sidney. 1992. "Mentalities, Political Cultures and Collective Action Frames." In Frontiers in Social Movement Theory, edited by Aldon D. Morris and Carol M. Mueller. New Haven, CT: Yale University Press. 174-202.

Tilly, Charles. 1995. Popular Contention in Great Britain, 1758-1834. Cambridge, MA: Harvard University Press.

Tsianos, Vassilis S., and Serhat Karakayali. 2010. "Transnational Migration and the Emergence of the European Border Regime: An Ethnographic Analysis." European Journal of Social Theory 13 (3): 373-87.

VAn Der Leun, JoAnne. 2003. Looking for Loopholes: Processes of Incorporation of Illegal Immigrants in the Netherlands. Amsterdam: Amsterdam University Press.

WACQUANT, LoIC J. D. 1989. "Towards a Reflexive Sociology: A Workshop with Pierre Bourdieu." Sociological Theory 7 (1): 26-63. 
Wallerstein, Immanuel. 2003. "Citizens All? Citizens Some! The Making of the Citizen." Comparative Studies in Society and History 45 (4): 650-79.

Walsh, Ally, and Mrrto Tsilimpounidi. 2012. "The Disappearing Immigrants: Hunger Strike as Invisible Struggle." Theory in Action 5 (2): 82-103.

Walters, William. 2008. "Acts of Demonstration: Mapping the Territory of (Non-) Citizenship." In Acts of Citizenship, edited by Engin F. Isin and Greg Marc Nielsen. London: Zed Books. 182-206.

Winner, Langdon. 1986. The Whale and the Reactor: A Search for Limits in an Age of High Technology. Chicago: University of Chicago Press.

Yuval-Davis, NiRA. 1997. "Women, Citizenship and Difference." Feminist Review 57: 4-27. 